\title{
KEY FACTORS FOR SELECTING AN OFFSHORING LOCATION
}

\author{
Bogdan SURDEA-BLAGA ${ }^{\mathrm{a} *}$ \\ a) Babeş-Bolyai University, Faculty of Economics and Business Administration, \\ Cluj-Napoca, Romania and \\ Country Director SYKES Enterprises Eastern Europe
}

Please cite this article as:

Surdea-Blaga, B., 2020. Key factors for selecting an offshoring location. Review of Economic Studies and Research Virgil Madgearu, 13(1), pp.137-160.

doi: 10.24193/RVM.2020.13.56.

\begin{abstract}
Location selection for a new site or center is one of the key elements for companies looking to move offshore their business processes. Both literature and practitioners have proposed different criteria and frameworks to support this decision and, in this paper, we have synthetized a new framework based on key location selection factors and risks. Sources used range from articles in academic journals and books on this topic to reports from management and consulting companies. In case of the academic journals, the key ones were identified, and a snowball approach was used to select relevant articles. While initial offshoring decisions have been made based on direct costs, like labor costs, the landscape is now more sophisticated, and several factors are to be considered. The assessment factors we identified are related to availability of foreign languages skills in the talent pool, experienced individuals in the market on the desired processes, potential for cost optimization, IT \& communications infrastructure, real estate availability, business climate and competition, city/region development plans, overall quality of life, and accessibility of the city.
\end{abstract}

Key words: offshoring; outsourcing; nearshoring; long-term decisions; framework

JEL Classification: F23O

(C) 2020 Alma Mater Publishing House. All rights reserved.

* Corresponding author. E-mail address: bogdan.surdea@sykes.com. 
Review of Economic Studies and Research Virgil Madgearu, 2020, 13(1)

\section{References:}

1. Ahsan, R.N., 2013. Offshoring and Wages. Australian Economic Review, 46, pp.110-118. https://doi.org/10.1111/j.1467-8462.2013. 12005.x.

2. Beimborn, D., 2008. Cooperative Sourcing. Wiesbaden: Gabler.

3. Bergeron, B.P., 2003. Essentials of Shared Services. New Jersey: John Wiley \& Sons.

4. Budzynska, K., 2017. Business process outsourcing sector in Visegrad Group. International Journal of Innovation and Learning, 21(1), pp.54-68. https://doi.org/10.1504/IJIL.2017.080753.

5. Budzynska, K., 2016. Offshoring sector in Poland. Oeconomia Copernicana,7(4),pp.635-651.https://doi.org/10.12775/oec.2016.035.

6. Bunyaratavej, K., Doh, J., Hahn, E.D., Lewin, A.Y. and Massini, S., 2011. Conceptual Issues in Services Offshoring Research: A Multidisciplinary Review. Group \& Organization Management, 36, pp.70-102. https://doi.org/10.1177/1059601110390996.

7. Bunyaratavej,K.,Hahn,E.D.andDoh,J.P.,2007.Internationaloffshoring of services: A parity study. Journal of International Management, 13, pp.7-21. https://doi.org/10.1016/j.intman.2006.05.002.

8. Click, R.L. and Duening, T.N., 2005. Business Process Outsourcing. The Competitive Advantage. New Jersey: John Wiley \& Sons.

9. Contractor, F.J., Kumar, V., Kundu, S.K. and Pedersen, T., 2012. Global outsourcing and offshoring. Cambridge: Cambridge University Press.

10. Corbett, M.F., 2004. The Outsourcing Revolution. Why It Makes Sense and How to Do It Right. Dearborn: Dearborn Trade Pub.

11. Cushman \& Wakefield, 2016. Where in the World? Business Process Outsourcing and Shared Service Location Index. Chicago: Cushman \& Wakefield.

12. Davenport, T.H. and Short, J.E., 1990. The New Industrial Engineering: Information Technology and Business Process Redesign. Sloan Management Review, 31(4), pp.11-27.

13. De Felice, F., Petrillo, A. and Autorino, C., 2015. Development of a Framework for Sustainable Outsourcing: Analytic Balanced Scorecard Method (A-BSC). Sustainability, 7, pp.8399-8419. https://doi.org/10.3390/su7078399. 
14. Deloitte, 2011. Shared Services Handbook. Hit the Road. London: Deloitte.

15. Demirbag, M., Glaister, K.W., 2010. Factors Determining Offshore Location Choice for R\&D Projects: A Comparative Study of Developed and Emerging Regions. Journal of Management Studies, 47, pp.1534-156o. https://doi.org/10.1111/j.1467-6486.2010.00948.x

16. Doh, J.P., Bunyaratavej, K. and Hahn, E.D., 2009. Separable but not equal: The location determinants of discrete services offshoring activities. Journal of International Business Studies, 40, pp.926943. https://doi.org/10.1057/jibs.2008.89.

17. Farrell, D., 2006. Smarter Offshoring. Harvard Business Review, pp.84-92.

18. Flores, R.G. and Aguilera, R.V., 2007. Globalization and location choice: an analysis of US multinational firms in 1980 and 2000. Journal of International Business Studies, 38, pp.1187-1210. https://doi.org/10.1057/palgrave.jibs.8400307.

19. Gerbl, M., McIvor, R. and Humphreys, P., 2016. Making the business process outsourcing decision: why distance matters. International Journal of Operations \& Production Management, 36(9), pp.10371064. https://doi.org/10.1108/ijopm-04-2014-0192.

20. Graf, M. and Mudambi, S.M., 2005. The outsourcing of IT-enabled business processes: A conceptual model of the location decision. Journal of International Management, 11(2), pp.253-268. https:// doi.org/10.1016/j.intman.2005.03.010.

21. Hahn, E.D., Bunyaratavej, K. and Doh, J.P., 2011. Impacts of Risk and Service Type on Nearshore and Offshore Investment Location Decisions. Management International Review, 51, pp.357-380. https://doi.org/10.1007/s11575-011-0078-z.

22. Halvey, J.K. and Melby, B.M., 2007. Business process outsourcing: process, strategies, and contracts, 2nd ed. Wiley.

23. Hanafizadeh, P., Zare Ravasan, A., 2020. A Systematic Literature Review on IT Outsourcing Decision and Future Research Directions. Journal of Global Information Management, 28(2), pp.160-201. https://doi.org/10.4018/JGIM.2020040108.

24. Hätönen, J., 2009. Making the locational choice: A case approach to the development of a theory of offshore outsourcing and internationalization. Journal of International Management, 15(1), pp.61-76. https://doi.org/10.1016/j.intman.2008.06.003. 
25. Hecker, A. and Kohleick, H., 2006. Explaining Outsourcing Failure. SSRN Electronic Journal. https://doi.org/10.2139/ssrn.939411.

26. Hepplestone, S., Holden, G., Irwin, B., Parkin, H.J. and Thorpe, L., 2011. Using technology to encourage student engagement with feedback: a literature review. Research in Learning Technology, 19. https://doi.org/10.3402/rlt.v19i2.10347.

27. Jafarnejad, A., Sherafat, A., Taghavi, N. and Talab, Z.M., 2013. Designing a Operational Evaluation Model for Outsourcing Decision Making by Effective Outsourcing Factors. International Journal of Academic Research in Business and Social Sciences, 3(7), pp.371383. https://doi.org/10.6007/ijarbss/v3-i7/6o.

28. Kakabadse, A. and Kakabadse, N., 2002. Trends in Outsourcing: Contrasting USA and Europe. European Management Journal, 20(2), pp.189-198. https://doi.org/10.1016/s0263-2373(02)00029-4.

29. Kearney, A.T., 2016. Global Services Location Index. [online] Available at: <https://www.prnewswire.com/news-releases/ at-kearney-releases-2016-global-services-location-indexgsli-300201927.html > [Accessed 17.02.2020].

30. Kedia, B.L. and Mukherjee, D., 2009. Understanding offshoring: A research framework based on disintegration, location and externalization advantages. Journal of World Business, 44, pp.250261. https://doi.org/10.1016/j.jwb.2008.08.005.

31. Kiteley, R. and Stogdon, C., 2014. Literature Reviews In Social Work. Thousand Oaks: SAGE Publications.

32. Lacity, M.C., Solomon, S., Yan, A. and Willcocks, L.P., 2011. Business process outsourcing studies: a critical review and research directions. Journal of Information Technology, 26, pp.221-258. https://doi. org/10.1057/jit.2011.25.

33. Lahiri, S. and Kedia, B.L., 2011. Co-evolution of institutional and organizational factors in explaining offshore outsourcing. International Business Review, 20(3), pp.252-263. https://doi. org/10.1016/j.ibusrev.2011.01.005.

34. Lecy, J.D. and Beatty, K.E., 2012. Representative Literature Reviews Using Constrained Snowball Sampling and Citation Network Analysis. SSRN Electronic Journal. https://doi.org/10.2139/ ssrn.1992601.

35. Lewin, A.Y. and Peeters, C., 2006. Offshoring Work: Business Hype or the Onset of Fundamental Transformation? Long Range Planning, 39, pp.221-239. https://doi.org/10.1016/j.lrp.2006.07.009. 
36. Lewin, A.Y., Perm-Ajchariyawong, N., Russell, J., 2011. Taking Offshoring to the Next Level. The 2009 Offshoring Research Network Corporate Client Survey Report. The Conference Board.

37. Liu, R., Feils, D.J., Scholnick, B., 2011. Why are different services outsourced to different countries? Journal of International Business Studies, 42, pp.558-571. https://doi.org/10.1057/jibs.2010.61.

38. Manning, S., Massini, S. and Lewin, A.Y., 2008. ADynamic Perspective on Next-Generation Offshoring: The Global Sourcing of Science and Engineering Talent. Academy of Management Perspectives, 22, pp.35-54. https://doi.org/10.5465/amp.2008.34587994.

39. Manning, S., Roza, M., Lewin, A.Y. and Volberda, H.W., 2009. Why Distance Matters: The Dynamics of Offshore Location Choices.

40. Marciniak, R., 2014. Global Shared Service Trends in the Central and Eastern European Markets. Entrepreneurial Business and Economics Review, 2, pp.63-78. https://doi.org/10.15678/ eber.2014.020306.

41. Merino, F. and Rodriguez, D.R., 2007. Business services outsourcing by manufacturing firms. Industrial and Corporate Change, 16, pp.1147-1173. https://doi.org/10.1093/icc/dtmo34.

42. Metters, R., 2008. A typology of offshoring and outsourcing in electronically transmitted services. Journal of Operations Management, 26, pp.198-211. https://doi.org/10.1016/j. jom.2007.02.004.

43. Michel, J.B., Shen, Y.K., Aiden, A.P., Veres, A., Gray, M.K., Pickett, J.P., Hoiberg, D., Clancy, D., Norvig, P., Orwant, J., et al., 2010. Quantitative Analysis of Culture Using Millions of Digitized Books. Science, 331, pp.176-182. https://doi.org/10.1126/science.1199644.

44. Morita, T., 2012. Dynamic analysis of location choice by multinational firms. Journal of Macroeconomics, 34, pp.1063-1076. https://doi. org/10.1016/j.jmacro.2012.07.004.

45. neoIT, 2006. Global City Competitiveness.

46. neoIT, 2005. Mapping Offshore Markets Update 2005.

47. Nicholson, B. and Aman, A., 2012. Managing attrition in offshore finance and accounting outsourcing. Strategic Outsourcing: An International Journal, 5, pp.232-247. https://doi. org/10.1108/17538291211291765.

48. Oshri, I., Kotlarsky, J. and Willcocks, L.P., 2015. The Handbook of Global Outsourcing and Offshoring, 3rd ed. Palgrave Macmillan UK. 
49. Pankowska, M., 2019. Information Technology Outsourcing Chain: Literature Review and Implications for Development of Distributed Coordination. Sustainability, 11, 1460. https://doi.org/10.3390/ su11051460.

50. Pedersen, T. and Pyndt, J., 2013. Managing global offshoring strategies. Copenhagen Business School Press.

51. Pisani, N. and Ricart, J.E., 2015. Offshoring of Services: A Review of the Literature and Organizing Framework. Management International Review, 56, pp.385-424. https://doi.org/10.1007/ s11575-015-0270-7.

52. Porter, M.E., 1985. Competitive Advantage. Creating and Sustaining Superior Performance. Free Press.

53. Ruivo, P., Rodrigues, J., Neto, M., Oliveira, T. and Johansson, B., 2015. Defining a Framework for the Development of ICT Services Nearshoring in Portugal. Procedia Computer Science, 64, 140-145. https://doi.org/10.1016/j.procs.2015.08.474.

54. Saunders, M., Lewis, P. and Thornhill, A., 2016. Research Methods for Business Students, 7th ed. Pearson Education Limited.

55. Schmeisser, B., 2013. A Systematic Review of Literature on Offshoring of Value Chain Activities. Journal of International Management, 19, pp.390-406. https://doi.org/10.1016/j.intman.2013.03.011.

56. Skipper, W., 2006. Services Offshoring: An Overview. Anthropology of Work Review, 27, pp.9-17. https://doi.org/10.1525/awr.2006.27.2.9.

57. Slepniov, D., Brazinskas, S. and Vejrum Waehrens, B., 2013. Nearshoring practices. An exploratory study of Scandinavian manufacturers and Lithuanian vendor firms. Baltic Journal of Management, 8, pp.5-26. https://doi.org/10.1108/17465261311291632.

58. Spruijt, P., Knol, A.B., Vasileiadou, E., Devilee, J., Lebret, E. and Petersen, A.C., 2014. Roles of scientists as policy advisers on complex issues: A literature review. Environmental Science \& Policy, 40, pp.16-25. https://doi.org/10.1016/j.envsci.2014.03.002.

59. Stringfellow, A., Teagarden, M.B. and Nie, W., 2008. Invisible costs in offshoring services work. Journal of Operations Management, 26, pp.164-179. https://doi.org/10.1016/j.jom.2007.02.009.

6o. Sturgeon, T.J., Boegh Nielsen, P., Linden, G., Gereffi, G. and Brown, C., 2013. Direct Measurement of Global Value Chains: Collecting Product- and Firm-Level Statistics on Value Added and Business Function Outsourcing and Offshoring, in: Mattoo, A., Wang, Z., Wei, 
S.-J. (Eds.), Trade in Value Added: Developing New Measures of Cross-Border Trade. World Bank Group, pp.289-319.

61. Surdea-Blaga, B., 2018. What makes a city attractive for business services centers? Cluj-Napoca case study. Transylvanian Review of Administrative Sciences, 55, pp.98-117. https://doi.org/10.24193/ tras.55e.7.

62. Tholons, 2009. Top 50 Emerging Outsourcing Destinations 2009.

63. Trapczynski,P.,Puslecki,L.andJarosinski,M.,2016.Competitiveness of CEE Economies and Businesses, 1st ed. Springer International Publishing.

64. van Eck, N.J., Waltman, L., 2009. Software survey: VOSviewer, a computer program for bibliometric mapping. Scientometrics, 84, pp.523-538. https://doi.org/10.1007/s11192-009-0146-3.

65. Worley, L., 2012. Outsourcing, Offshoring, Nearshoring, Onshoring - What's Going On? Legal Information Management, 12, pp.9-11. https://doi.org/10.1017/s1472669612000072. 